\title{
The Evolution of Infrastructure Investment of Korea
}

\author{
Kilkon Ko*
}

\begin{abstract}
Although analysts have explored many facets of economic growth of Korea over the last decades, infrastructure investment policies have been discussed in terms of a simple developmental state framework that emphasizes the role of bureaucracy. This paper claims that infrastructure investment is a function of interactive processes affected by demand, supply, politics, and administrative reaction. While the Korean government did invest in infrastructure in advance of the growth of demand for it in the 1970s, it has made its major infrastructure investment since the 1980s. Also, while strong political leadership is frequently lauded, the problems with the Gyeongbu expressway and the four-rivers project suggest that political leadership without adequate rational planning and policy analysis can have undesirable effects. Finally, facing budget constraints and pressure to make efficient use of limited resources, the Korean government has sought to institutionalize a systematic process for managing infrastructure investment. Hence, the development and utilization of relevant policy analysis and evaluation methods is necessary.
\end{abstract}

Key Words: infrastructure, politics, policy analysis

\section{INTRODUCTION}

It is common knowledge that infrastructure investment is essential for economic development. As its etymology implies, infrastructure comprises the "installations that form the basis for any operation or system" (Online Etymological Dictionary). Individual firms have to pay direct and indirect costs to finance the production of their goods without the relevant provision of infrastructure. An indication of just how an extensive and efficient infrastructure is critical for economic development is that infrastructure is the second pillar of the World Economic Forum's global competitiveness index. In fact, the correlation coefficient of the level of infrastructure and overall competitiveness of

* Kilkon Ko is an associate professor in the Graduate School of Public Administration at Seoul National University. E-mail: kilkon@snu.ac.kr.

Manuscript received February 10, 2014; out for review March 3, 2014; review completed April 14, 2014; accepted April 17, 2014.

The Korean Journal of Policy Studies, Vol. 29, No. 1 (2014), pp. 123-145.

(C) 2014 by the GSPA, Seoul National University 
a country ranged as high as between 0.79 and 0.96 in the period 1999-2010. Despite the importance of infrastructure, however, it is a rare form of capital in most lessdeveloped countries owing to a scarcity of resources, which does not simply derive from a lack of resources but also from a waste of whatever limited resources a country might have to begin with.

Public economics (Stiglitz, 2000; Weimer \& Vining, 2005) predicts the possibility of both under- and oversupply of infrastructure. Its undersupply is predicted by its nature as both a nonexcludable and nonrivalrous resource. The market would not voluntarily supply infrastructure given that it cannot exclude nonpaying consumers from using infrastructure and given that one's use of infrastructure does not reduce the others' use of it. Due to the nonexclusive and nonrivalrous character of infrastructure, private companies would not be able to use price mechanisms to make profits were they to supply it. Consequently, they have less incentive to meet the demand of citizens and provide less in the way of infrastructure than is socially desirable.

On the other hand, oversupply is predicted by the nature of politics. Electorates consider the construction of infrastructures in their districts to be the responsibility of politicians, and so promising to build infrastructure improves a candidate's chance of being elected. At the same time, private investors want the government pour more money into infrastructure to support their business and are also often willing to provide campaign funds for politicians in exchange for more infrastructure investment. As the consequence, politicians and local governments tend to seek a larger investment budget than they need. This is the primary reason that infrastructure investment is closely related to pork barreling politics in which politicians sacrifice national interests by overspending to satisfy local interests. Politicized decision-making processes result in the oversupply of infrastructure. How to supply infrastructure is thus both an economic and political question (Flyvbjerg, Bruzelius, \& Rothengatter, 2003).

The infrastructure investment experience of Korea is highly impressive given its quantitative and qualitative expansion over the last six decades. After the end of the Korean civil war in 1953 , the road length of Korea was $26,128 \mathrm{~km}$. Yet the proportion of roads that were paved was only $2.3 \%(601 \mathrm{~km})$, and there was no expressway in Korea before 1968. As of 2011, however, the road length was $105,930 \mathrm{~km}$, among $85,120 \mathrm{~km}$ of which was paved. Korea also opened Incheon International Airport, rated the best airport worldwide by Airport Council International for seven years in a row (2005-2012), despite severe competition with China, Singapore, and Japan. Busan Port was also ranked the fifth container port in the world as of 2012 and has become one of hub ports in Asia. Developing countries can learn from this remarkable expansion of infrastructure in Korea. 
In contrast to Korea, other developing countries have suffered from failing to sufficiently invest in infrastructure. Sometimes, international organizations that supply funds to developing countries stipulate how those funds are to be spent without taking domestic needs into account. In other cases, the decision as to how to invest money is highly affected by political interests that are frequently linked with corruption. Such problems cause the supply-demand gap and a failure in effective utilization of limited resources for infrastructure investment.

This paper aims at reviewing the evolution of Korean government's infrastructure investment policy by focusing on how the supply and demand of the infrastructure stock has changed in line with the economic growth of Korea. While the economic miracle of South Korea has been highly praised in scholarly literature (Amsden, 1989; Lucas, 1993), little attention has been paid to how the Korean government has expanded its infrastructure by coping with inefficient supply. One might expect that such an astonishing growth in Korea's infrastructure is natural considering the economic development of the country. However, as this article argues, the Korean government built the supply infrastructure in advance of demand. More importantly, the government successfully rationalized infrastructure investment decisions.

\section{KOREA'S DEVELOPMENT OF INFRASTRUCTURE: A BRIEF REVIEW OF INVESTMENT TRENDS}

\section{Definition of Infrastructure}

There is no standard definition of infrastructure. In development economics, infrastructure is defined as "social overhead capital" (Hirschman 1958). The traditional definition of social overhead capital put emphasis on its "indirect" use of economic activities to improve productivity, which is distinguishable from economic capital that is directly connected with the production of a firm. As the literal meaning of "overhead" suggests, social overhead capital is related to "the general, fixed cost of running a business, as rent, lighting, and heating expenses, which cannot be charged or attributed to a specific product or part of the work operation" (http://dictionary.reference.com/ browse/overhead ).

The emphasis on the economic function of social economic capital has been modified, as certain types of public goods such as parks, museums, the internet, the water supply and sewage system, education, and public health investment transcend it. In addition, while transportation service can be used to spur economic development, it also significantly contributes to improving the quality of life of citizens by enhancing 
accessibility among regions and people. Hence, the term "social economic capital," which emphasizes economic function, is less valid than the term "infrastructure," whose function is also related to the quality of life of citizens.

Along with the debate over the function of infrastructure, what attributes characterize infrastructure is also controversial. Nonrivalry and nonexcludability, the two attributes of the traditional definition of infrastructure in development economics, are primary characteristics of public goods, such as roads and railways. For instance, if a driver uses a public road without causing congestion, the use of the road by other drivers at the same time does not degrade the quality of it. Moreover, if the government allows users to access the road without charge, there is no ground on which to exclude drivers who do not have the ability to pay.

The recent advancement of payment systems and the shortage in the supply of infrastructure followed by privatization, however, have weakened the nonrivalrous and nonexcludable features of infrastructure. For instance, energy, the railroad, harbor, airport, internet, and even the expressway can be rendered excludable by the imposition of a pricing system. Benefiting from the advancement of electronic charging systems that depend on information technology, the supplier can accurately apply the user-pay rule at low cost. Also, the congestion and the limited capacity of various forms of transportation invalidate the nonrivalry assumption. London and Singapore, for instance, apply a congestion charge to drivers, admitting the rivalrous nature of metropolitan roads. The supporters of the privatization of infrastructure suggest that nonrivalry and nonexcludability are not fundamental attributes of infrastructure and argue that infrastructure can indeed be provided by the private sector.

Monopoly is another attribute of infrastructure. When the road is provided by a private company, the company can enjoy a monopoly if there are no alternative roads to use. In such a case, the user fee can be set higher than the marginal cost, producing a deadweight loss. Monopoly has other negative effects; it results in the undersupply of infrastructure and gives rise to a political lobby for protecting the monopolistic power of the suppliers. The monopolistic aspect of the private provision of infrastructure leads to market failure. To remedy this situation, therefore, many claim that the government should intervene by providing and managing infrastructure. On this view, infrastructure is understood as publicly provided goods rather than public goods.

The changing understanding of infrastructure is well reflected in the influx of foreign direct investment (FDI) in developing countries in the 1990s. Despite the investment risk due to political instability, weak institutions, and government regulation, FDI has grown around the world. Ramamurti and Doh (2004, p. 151) list a number of reasons that might account for this anomalous phenomena: 
Foreign investors may have believed: (1) that infrastructure sectors were losing their "natural monopoly" characteristics; (2) that first-movers would profit handsomely from the emerging globalization of these sectors; (3) that novel techniques like project financing would reduce their risks sharply; (4) that the climate for FDI in developing countries had changed fundamentally in the 1990s; and (5) that host developing countries would not expropriate foreign-owned infrastructure assets as they had in the past.

However, Ramamurti \& Doh also point out that FDI in infrastructure has not dissipated in the twenty-first century, which challenges these various explanations. Private companies and public sector conflicts are more common, and the risk of FDI is higher than expected. Hence, we can conclude that other factors like the role of the government and the nature of public goods are still important in infrastructure investment in developing countries.

To sum, the conceptual definition of infrastructure is less theoretical than practical. Although the fundamental differences between infrastructure and private goods have been attenuated over the years, the idea that the government has a proactive role to play in providing infrastructure is still valid and practically supported.

\section{The Trend of Infrastructure Investment Supply and Demand in Korea}

Infrastructure investment is the result of interactions between the demands of the private sector and the suppliers which is mainly the government. To offer a balanced account, we need to assess the role of the private and public sector equivalently. However, as the Korean government plays a proactive role in infrastructure investment, the following discussion is mainly limited to how the Korean government has guided infrastructure investment in Korea.

After the Korean civil war (1950-1953), the Korean government had to rebuild its infrastructure, but it did not have enough financial resources to do so, nor did it have a systematic master plan to guide infrastructure investment. To overcome this challenge, in 1962, the Korean government introduced the first of what would be a series of economic development plans. The five-year economic development plan had been was successively revised until 1996, reflecting changes in the economic and political situation of Korea. It also clarified how infrastructure investment should be made so as to achieve the planned economic development.

The five-year economic development plan reflected a number of basic principles. The first was that the government should play a significant role in economic development. The Korean government tightly controlled economic development, using the 
economic development plan to guide the allocation of budgets and to prioritize policies. The president and cabinet members also monitored the achievement of the proposed targets of the development plan every year.

The second was that economic development could be achieved through industrialization following the structural change theory proposed by W. Arthur Lewis (Todaro \& Smith, 2003). According to Lewis's theory, economic development entails a transition from an agricultural society to a modernized, urbanized, and industrialized society with larger manufacturing and service industries. The Korean government decisively introduced policies for nurturing secondary and tertiary industries, and it selected regional growth centers that it intended to provide infrastructures for.

The third was that the lack of financial resources could be remedied by seeking foreign capital. The major companies that benefited from this influx of foreign capital were not owned by the foreign investors. Instead, private companies borrowed the money from the foreign investors, and the Korean government offered a credit guarantee to them. Notably, while foreign capital was an important financial source of infrastructure investment, the government maintained the authority to distribute the money. One result of the government's allocation of the foreign loans to a small number of companies and the prevention of foreign investors from ownership stakes in private companies was the formation of conglomerates (chaebol) in Korea.

The first five-year economic development plan (1962-1966) focused on light manufacturing industries like the textile industry. Unlike other developing countries that attempted to increase self-sufficiency and the domestic market, Korea sought economic growth by encouraging exports. To expedite exporting, the Korean government built industrial complexes and provided roads and railways to them.

In the second five-year economic development plan (1967-1971), the Korean government began to invest more in heavy industry, including the chemical, steel, and machinery industries. To improve transportation of raw materials to the industrial complexes, the government electrified the Jungang, Youngdong, and Taebak railways, which passed through mountainous and mining areas. As these railways were mainly used for transporting natural resources, the expansion of the railway to the regions did not much improve the accessibility of trains for passenger traffic.

The takeoff stage of the Korean government's infrastructure development started in the 1970s. As shown in table 1, the urbanization rate in Korea was only $50.1 \%$ in 1970. Moreover, there were only 126,000 registered cars. Despite the low urbanization rate, Korea experienced the upsurge of population in metropolitan areas, especially Seoul, the capital of Korea. Seoul's population in 1960 was around 244.5 million but had increased to 544.3 million by 1970. Such an increase in the population of metropolitan areas was a result of unbalanced economic development, as the Korean government 
Table 1. Korean Social and Economic Indicators, 1970-2010

\begin{tabular}{l|r|r|r|r|r|r|r|r|r}
\hline & 1970 & 1980 & 1990 & 2000 & 2010 & \multicolumn{4}{|c}{ Annual Growth Rate } \\
\cline { 7 - 10 } & 32,241 & 38,123 & 42,869 & 47,008 & 48,989 & $1.69 \%$ & $1.18 \%$ & $0.93 \%$ & $0.41 \%$ \\
\hline $\begin{array}{l}\text { Population } \\
(1,000)\end{array}$ & 50.1 & 68.7 & 81.9 & 87.7 & 90.9 & $3.21 \%$ & $1.77 \%$ & $0.69 \%$ & $0.36 \%$ \\
\hline $\begin{array}{l}\text { Urbanization } \\
\text { rate (\%) }\end{array}$ & 2,775 & 39,110 & 191,383 & 603,236 & $1,172,803$ & $30.29 \%$ & $17.21 \%$ & $12.17 \%$ & $6.87 \%$ \\
\hline $\begin{array}{l}\text { GDP } \\
\text { (million USD) }\end{array}$ & 126 & 527 & 3,394 & 12,059 & 17,941 & $15.38 \%$ & $20.47 \%$ & $13.52 \%$ & $4.05 \%$ \\
\hline $\begin{array}{l}\text { Number of } \\
\text { Cars (1,000) }\end{array}$ & 126 & & & & & & & & \\
\hline
\end{tabular}

had used the country's limited national resources to develop strategically selected cities and regions. To mitigate the urban traffic problem, in 1972 Korea began constructing the subway system in Seoul.

In the 1970s, the government also expanded the road network to connect the regional growth centers. The Gyeongbu expressway was completed in 1971, and other interprovincial highways began to be constructed in the late 1970s. Although the investment was to some extent designed to meet the demand for more roads, the primary motivation was economic development. As economic development was the national priority, an infrastructure investment plan was created in accordance with the five-year economic development plans. Also, as infrastructure is closely related to regional development, the Korean government introduced the first national land development plan (1972-1981), which came to shape infrastructure investment.

\section{Road and Railway Supply}

Official statistics count both the paved and unpaved roads. As direct road investment is more correlated with the length of paved road, we need to exclude the unpaved road length. As the annual economic growth rate in the 1970s (30.29\%) was higher than the 1980s $(12.17 \%)$ as shown in table 1, we might expect a rapid increase in the number of roads in the 1970s. However, as shown in figure 1, road supply grew dramatically in the 1980s. In the 1980s, as shown in table 1, the number of cars increased at an annual rate of around $20.5 \%$. The government ought to have provided more roads in the 1970s, but considering it can take five to seven years to plan and build a road and how many new roads were needed, it was not possible for it to do so. This widened the gap between the supply of and demand for road. 
Figure 1. Paved-Road Length, 1961-2011

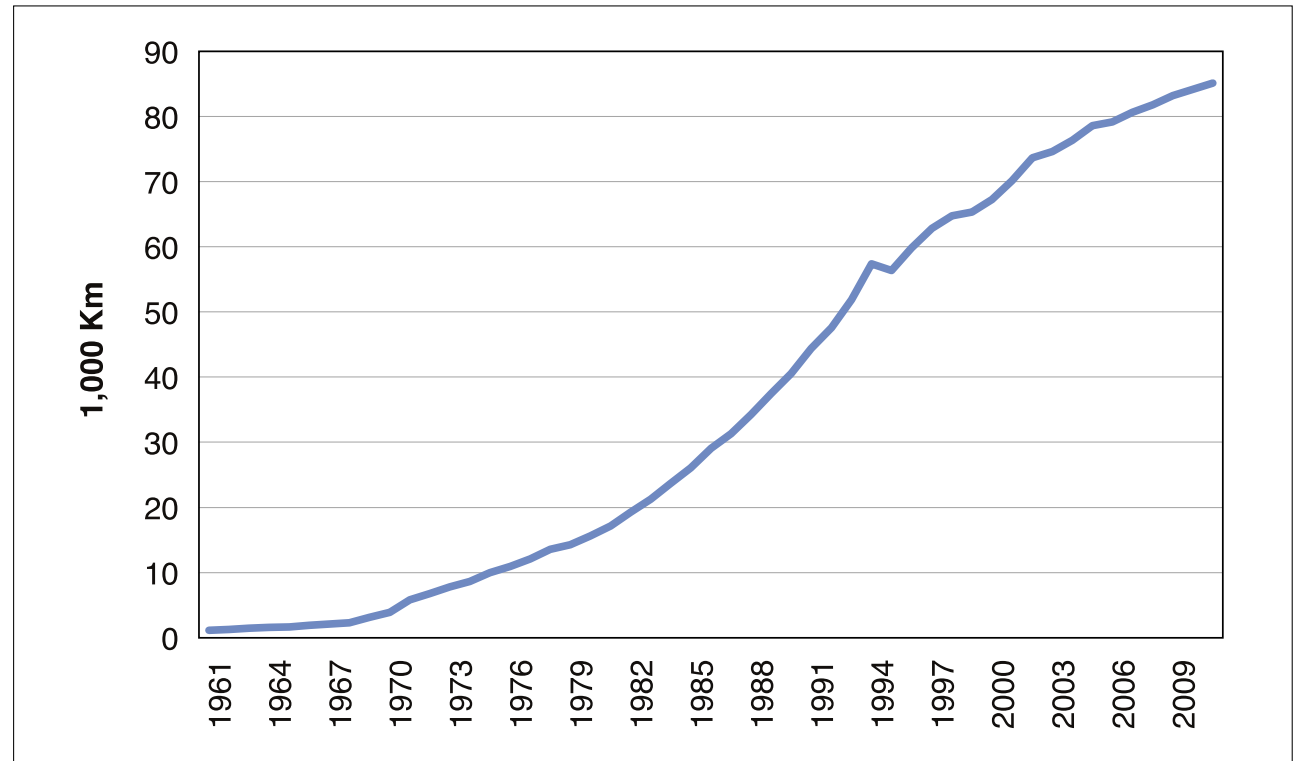

Source: Korea Transportation Database, www.ktdb.go.kr

Aware of the serious shortage of roads, the Korean government began to invest more in them. One notable policy change was the establishment of the special transportation fund in 1994, which was financed by the fuel tax. While the amount of the special transportation tax changed over years, it is almost \$15 billion USD as of 2012. With this special transportation fund, the Korean government has access to the financial sources to fund transportation infrastructure investment that are less affected by budget shortfalls.

The continuous growth of road networks has raised two major concerns: inefficiency and rising maintenance costs. As the most economically valuable roads have by now been built, the economic benefits from new projects are limited. As the result, rapid growth in road supply is no longer justified. In addition, since 2005 , more than $30 \%$ of the total budget for roads has begun to be used for maintenance rather than new construction. These factors have slowed down the increase of the number of roads in Korea since the late 2000s.

As shown table 2, the congestion costs due to shortage of roads are still very high. As of 2010, congestion costs were around \$28 billion USD, and most of them arise in urban areas. This implies that megaprojects connecting different regions are no longer economically justifiable. Instead, a new investment policy that abates urban congestion costs is necessary. Given the limited amount of land available, this new policy should 
Table 2. Korean Congestion Costs, 2004-2010 (in $\$ 100,000$ USD)

\begin{tabular}{|c|c|c|c|c|c|c|c|}
\hline & 2004 & 2005 & 2006 & 2007 & 2008 & 2009 & 2010 \\
\hline Total Congestion Costs & 231,156 & 235,396 & 246,215 & 261,723 & 269,027 & 277,055 & 285,090 \\
\hline $\begin{array}{c}\text { Regional } \\
(\%)\end{array}$ & $\begin{array}{l}91,305 \\
(39.5)\end{array}$ & $\begin{array}{l}90,937 \\
(38.6)\end{array}$ & $\begin{array}{l}91,803 \\
(37.3)\end{array}$ & $\begin{array}{l}96,838 \\
(37.0)\end{array}$ & $\begin{array}{l}98,810 \\
(36.7)\end{array}$ & $\begin{array}{c}100,643 \\
(36.3)\end{array}$ & $\begin{array}{c}104,361 \\
(36.6)\end{array}$ \\
\hline $\begin{array}{l}\text { Urban } \\
(\%)\end{array}$ & $\begin{array}{c}139,851 \\
(60.5)\end{array}$ & $\begin{array}{c}144,459 \\
(61.4)\end{array}$ & $\begin{array}{c}154,412 \\
(62.7)\end{array}$ & $\begin{array}{c}164,885 \\
(63.0)\end{array}$ & $\begin{array}{c}170,217 \\
(63.3)\end{array}$ & $\begin{array}{c}176,412 \\
(63.7)\end{array}$ & $\begin{array}{c}180,729 \\
(63.4)\end{array}$ \\
\hline
\end{tabular}

not call for more supply of roads in the cities. Instead, the government has to improve the management of traffic systems by utilizing new information technologies, public transportations, and railways.

Railway supply, in contrast to road supply, was pretty static until the mid-2000s. As shown in figure 2, railway length did not change until 2003. To some extent, the reason there was less investment in the railways was because for a lot of money was spent on the Gyeongbu high-speed rail and subways.

By the 1990s, the government was coming under fire for the lack of investment in the railways. In response to the criticism, in the 2000s it tried to improve the quality of railways by changing the single-track railway to an electrified double-track. The primary

Figure 2. Railway Length, 1980-2010

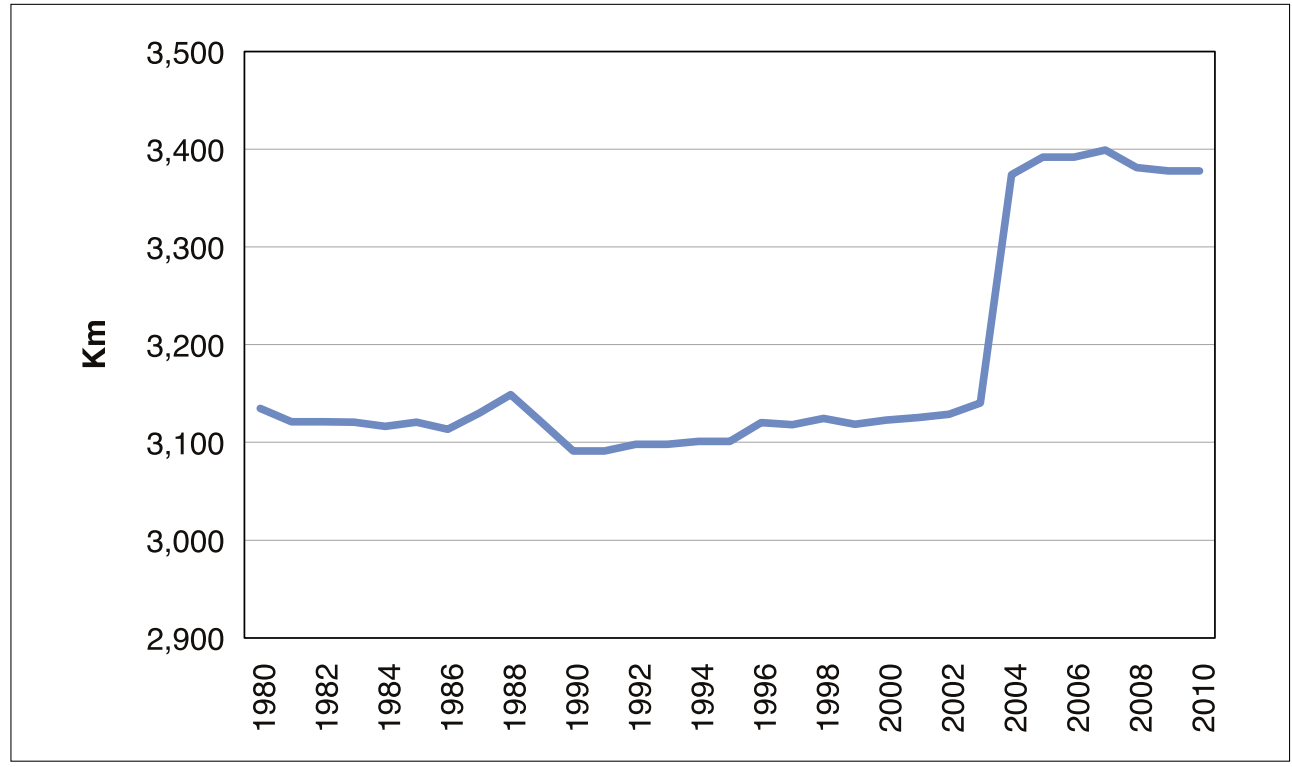

Source: Korea Transportation Database, www.ktdb.go.kr 
justification for this investment was that people would switch from using roads to using the railways for their trips. However, the concentration of the population in Seoul and Gyungi regions and the high accessibility of cars for door-to-door trips has meant that there has not been a significant increase in the number of people using the railways. As the result, while some support more investment in the railways, arguing that trains are more environmentally friendly, railway traffic is still rather light, except for on the Gyeongbu line, which many people use for long-distance travels.

\section{Road and Railway Demand}

Road demand is closely related to the number of registered cars. As mentioned, the number of cars began to rapidly increase in the mid-1980s (see table 1). Between 1970 and 1984, the number of registered cars increased six times. However, the number increased eight times between 1985 and 1998. The PPP GDP per capita of South Korea in 1986 was around $\$ 4,900$ USD, allowing more people to buy cars for travel and business purposes.

Railway demand shows the different pattern from road demand. As shown in figure 3 , the number of passengers using the railway has continuously increased since the 1980s. One might interpret this trend as the evidence of more demand for railways for

Figure 3. Number of Railway Passengers, 1980-2010

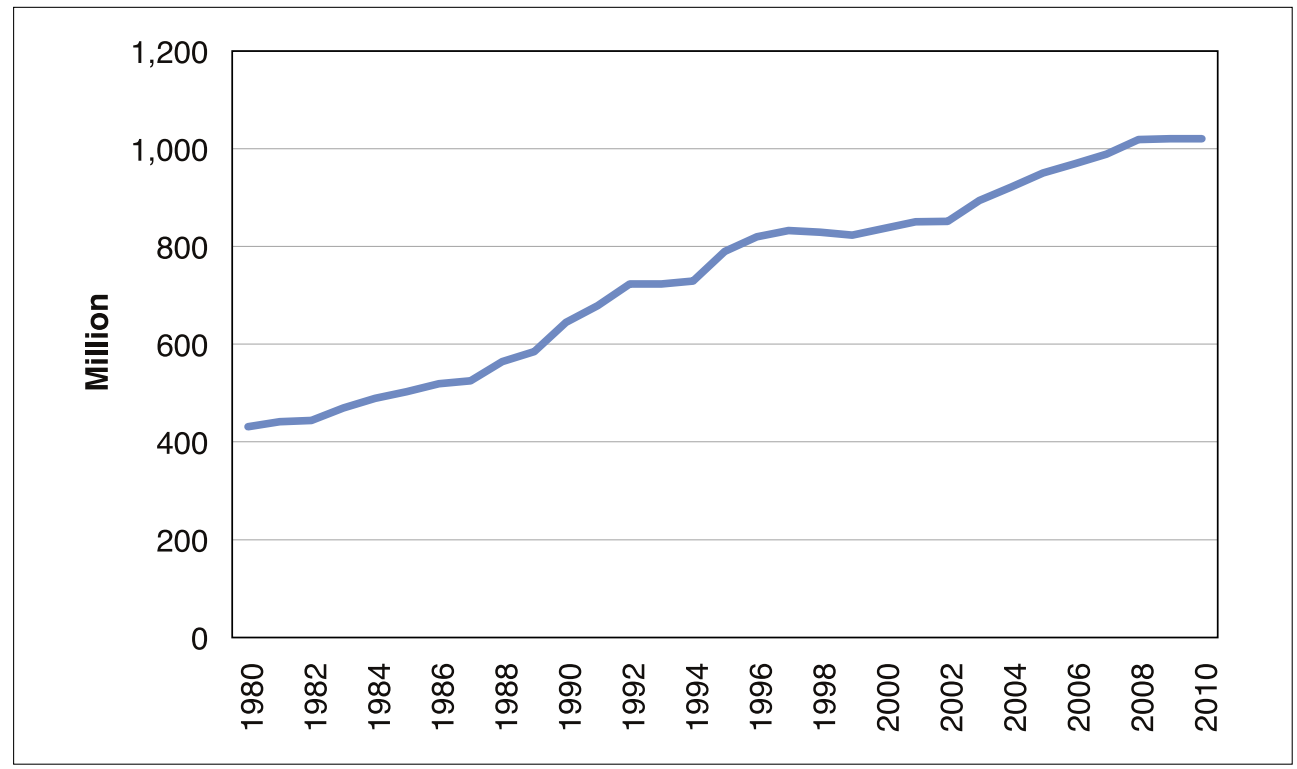

Source: Korea Transportation Database, www.ktdb.go.kr 
Figure 4. Rail Freight, 1978-2010

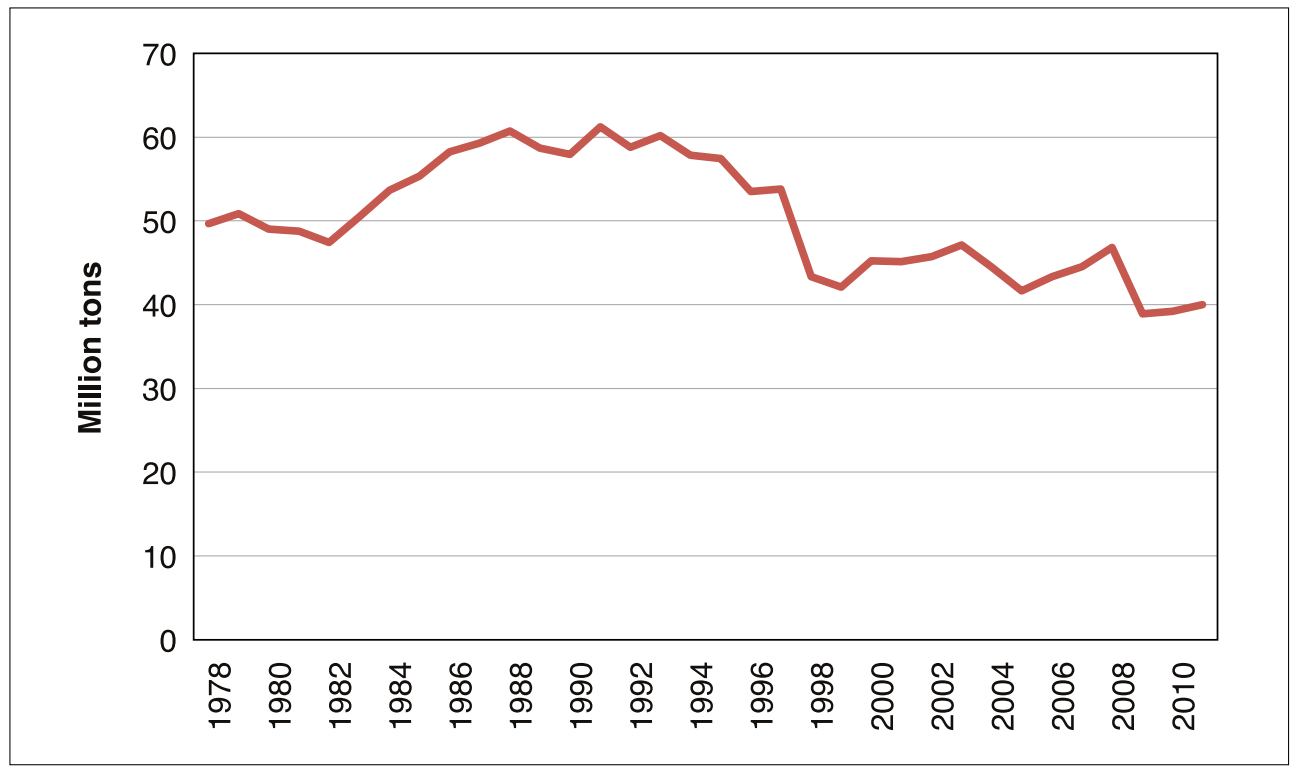

Source: Korea Transportation Database, www.ktdb.go.kr

passenger travel. However, we should distinguish passenger travels between the regions from travels within the Seoul metropolitan region. The increase of railway passengers is mainly indebted to the latter, not the former. In the case of the number of passengers traveling to different regions, railway use decreased 5.9\% between 1995 and 2012. This implies that the railway as a mode for passenger traffic has weakened. In addition, as shown in figure 4, the amount of freight transported by the railway increased until mid-1990s but gradually decreased thereafter. This suggests that the role of railway as a mode for transporting freight as well as passenger traffic has been diminished.

\section{Transportation Mode Change}

The primary mode of transportation in Korea is the road. In 1970, 95.2\% of passengers traveled by road, $4.6 \%$ by railway, $0.2 \%$ by ship, and $0.03 \%$ by airplane. By 2009 , the ratios had changed significantly: $74.8 \%$ traveled by road, $8.0 \%$ by railway, $17 \%$ by subway, $0.1 \%$ by airplane, and $0.1 \%$ by ship. The heavy reliance on the subway is the related to urbanization and the concentration of the population in the Seoul metropolitan region, where more than $25 \%$ of population live.

A significant proportion of freight traffic, like passenger traffic, is found on the 
Table 3. Proportion of Passenger Traffic by Mode of Transportation, 1970-2009 (\%)

\begin{tabular}{c|c|c|c|c|c}
\hline & Road & Railway & Subway & Ship & Airplane \\
\hline 1970 & 66.0 & 32.3 & 0.0 & 0.8 & 0.9 \\
\hline 1980 & 73.2 & 24.7 & 1.1 & 0.5 & 0.6 \\
\hline 1990 & 66.3 & 22.1 & 8.3 & 0.4 & 3.0 \\
\hline 2000 & 56.1 & 21.5 & 16.5 & 0.1 & 0.2 \\
\hline 2009 & 61.3 & 19.1 & 14.7 & 0.5 & 4.3 \\
\hline
\end{tabular}

Source: KOTI, 2012, 10. Passenger traffic volume is measured by million passenger-Km.

Table 4. Proportion of Freight Traffic by Mode of Transportation, 1970-2009 (\%)

\begin{tabular}{c|c|c|c|c}
\hline & Road & Railway & Ship & Airplane \\
\hline 1970 & 59.3 & 30.3 & 10.4 & 0.005 \\
\hline 1980 & 60.5 & 28.4 & 11.1 & 0.01 \\
\hline 1990 & 63.8 & 17.2 & 19 & 0.05 \\
\hline 2000 & 73.4 & 6.7 & 19.9 & 0.06 \\
\hline 2009 & 79.2 & 5.1 & 15.7 & 0.04 \\
\hline
\end{tabular}

Source: KOTI, 2012, 13.

roads. In 1970, 59.3\% of domestic freight was transported by road and $30.3 \%$ by railway. Notably, the used of railway to transport freight decreased in the 2000s. Its contribution to freight traffic decreased to $5.1 \%$.

In sum, infrastructure investment in Korea has largely taken the form of road investment. While the railway was regarded as an important transportation mode for conveying the freight in the 1970s, its role has gradually decreased. In defiance of expectation, major infrastructure investment did not occur in the 1970s, when the economy was growing rapidly. Instead, it was only once the GDP per capita reached to $\$ 5,000$ USD and the purchasing power of citizens increased in the 1980s that the rapid increase in road supply took place.

\section{Political Leadership and Infrastructure Investment}

Most literature (Amsden, 1989) dealing with the economic development of Korea suggests that the authoritarian leadership of President Park Jung-hee should be counted as one of major factors contributing to it and frequently cite the Gyeongbu expressway 
as a good example of his successful political leadership in infrastructure investment. In contrast, the recent four-rivers development project (2009-2012) under the leadership of President Lee Myung-bak turned out to be highly disappointing in its negative impacts on environment. A review of these two cases can provide us with insight into the pros and cons of political leadership in infrastructure investment. In the following, we critically review these two cases and provide a counterexplanation to the positive role attributed to political leadership.

The idea for the Gyeongbu expressway (a $428 \mathrm{~km}$ expressway from Seoul to Busan) was proposed by then-President Park in 1967 during his presidential election. President Park did not have any concrete ideas as to the financial burden of the investment or the benefits and costs of the project. The original planning team proposed W38.4 billion but cut that to $W 33$ billion at the vice ministry meeting regarding the economy. Once the project was being seriously considered, different figures were proposed by different organizations. The Ministry of Construction proposed $\$ 65$ billion, while Ministry of Finance proposed $\mathbf{W} 33$ billion, Seoul City $\$ 18$ billion, the Korean Army Corps of Engineers $\$ 490$ billion, and the Hyundai construction company $\$ 28$ billion. The Korean government finalized a budget of $\$ 33$ billion for the project in 1968 , but the budget increased $30 \%$ to $\$ 44$ billion in $1969 .{ }^{1}$ Such a huge variation in estimated project costs suggests that neither the president nor the Korean government had the capacity to calculate the economic costs of the expressway investment.

The financing of the project was also problematic. When President Park first announced the Gyeongbu expressway project, he claimed that the World Bank and other international organizations would fund it. ${ }^{2}$ Also, some claimed that the project costs were being financed by property claims against Japan. However, $95.6 \%$ of the total projects cost was financed domestically by raising petroleum tax and appropriating money from other budgets.

The expressway was also not highly used. Between 1971 and 1979, the number of registered cars increased only from 140,000 to 490,000. As noted (see figure 3), a significant increase in the number of cars only occurred beginning in the early 1980s. After the construction of the Gyeongbu expressway, the government realized that demand for long-distance travel was low. As the consequence, the length of the expressway changed little between $1975(1,142 \mathrm{~km})$ and $1983(1,245 \mathrm{~km})$.

Finally, the priority the investment was given was misplaced. Given that the total construction costs of the project were around $8.4 \%$ of the 1970 budget of the Korean

1. Korean National Archives, http://theme.archives.go.kr/next/gyeongbu/roadStatistics02.do.

2. Korean National Archives, http://theme.archives.go.kr/next/gyeongbu/roadCommemoration 01.do. 
government, it could not spend money on other infrastructure investments, such as, in particular, provincial roads. While both the opposition and majority party agreed to spend more money on the construction of roads, unlike President Park, the opposition party leaders such as Kim Dae-jung argued giving higher priority to national and provincial roads than the expressway. Because it turned out that the Gyeongbu expressway was not urgently needed as the government expected, the Park administration shifted its policy direction, improving the quality of national and provincial roads rather than constructing another expensive expressway. Hence, the percentage of paved national roads increased from $28.3 \%$ in 1971 to $60.7 \%$ in 1979 and that of provincial roads from $2.2 \%$ to $10.6 \%$.

The other interesting case is the four-rivers development project initiated by President Lee Myung-bak in 2009. The project costs were around $W 22.2$ trillion, and it was completed in two years. President Lee justified the project by arguing that it would contribute to managing water resources systematically, improve environmental quality, and boost the economy.

However, compared to the Gyeongbu expressway project, the four-rivers project had less support from citizens and opposition parties. According to public opinion polls, the majority of citizens $(51.0 \%)$ were opposed to undertaking the project. ${ }^{3}$ The opposition parties and civil society organizations protested the project due to its economic infeasibility and environmental problems and because they believed it would be ineffective in achieving the proposed goals. More importantly, the projected was planned without the benefit of a proper policy analysis, for its master plan was made within six months. Given that most infrastructure investment requires at least three years for planning and policy analysis, it seems unlikely that the six months it took to design a plan for the four-rivers development policy was enough. Of course, it is too early to evaluate the effect of the four-rivers project. However, one thing that is clear is that the political decision to proceed without the proper policy analysis having been undertaken in the planning stages was not appropriate in a democratic society.

These two cases suggest that although strong political leadership can play a significant role in infrastructure investment decisions, the choices a given administration makes are not necessarily the best ones. Of course, Park and Lee governed in different institutional settings, which limits our ability to draw generalizable conclusions. Yet our review suggests that strong political leadership does not guarantee a given infrastructure investment will be sound.

3. The survey was done by a survey company, Real Meter, in December 2009. In the survey, only $35.9 \%$ of respondents supported the project. 


\section{INSTITUTIONALIZATION OF THE INFRASTRUCTURE INVESTMENT PROCESS FROM PLANNING TO POSTEVALUATION}

\section{The Demand for Rational Public Investment Based on Policy Analysis}

Before the 1990s, the priority of investment projects in Korea was determined according to their contribution to economic development rather than by considerations of regional equity or convenience of users before the 1990s. A few authoritative decision makers decided which projects had priority, and public participation was limited, nor did the process take other values much into account. Reflecting this lack of wider input, there were no official guidelines for cost-benefit analyses proposed by the Korean government before 1982. There were almost two dozen academic articles dealing with public investment analysis methods such as cost-benefit analysis published before the 1980 s, but most of them related to general planning and not to specific sectors. 4 Hence, policy analysis for infrastructure projects mainly covered physical design or ways to minimize construction costs.

Along with economic growth and democratization, however, the demand for rational investment decision making grew in the 1990s. The weakened political leadership of the central government brought out the conflicts that existed among interest groups. Local governments began to devise their own regional development plans in the 1990s. ${ }^{5}$ When major national level infrastructure projects were proposed, however, citizens paid more attention to various problems such as land use, housing, job creation, regional equity, and environmental impact. Multiple interest groups established their own priorities. Moreover, some megaprojects were huge failures. For instance, the Gyeongbu high-speed railroad, the Busan second subway line, Yeo-Su airport, and the Sae-Man-Geum landfill saw at least twofold cost increases and three years of project delay (MOCT, 1999). These projects were independently implemented as a result of political considerations, not as part of a systematically analyzed higher-level plan.

The growing demand for policy analysis also comes from the need to coordinate of the local and central governments' interests. Local governments tried to launch as many projects as possible and tended to emphasize the importance of regional development.

4. I reviewed articles from DBPIA, www.dbpia.co.kr, and http://kiss.kstudy.com.

5. The major research institutes of local governments were established in the 1990s and include Seoul Development Institute (1992), Busan Development Institute (1992), Kyeonggi Development Institute (1994), and Incheon Development Institute (1995). 
In contrast, the central government had to allocate budgets according to the national agenda rather than in response to regional issues. Although we can resolve such a tension between local and central governments with political bargains, a rational decisionmaking process can help politicians and public officials arrive at an informed decision. At the same time, cost-benefit analysis and other rational decision-making techniques can improve the transparency of decisions, allowing others to straightforwardly evaluate the validity of the analysis results.

Finally, infrastructure investment based on policy analysis can prevent the porkbarrel spending of politicians for their district's projects at the expense of social welfare. For instance, although the National Assembly has no authority to increase the executive branch's proposed budget, politicians can indirectly ask the executive branch to insert their district's projects into the budget proposal that is then resubmitted to the National Assembly for a vote. Policy analysis can undermine such political influence over infrastructure investment by holding politicians responsible for their approval of economically infeasible projects and thereby making it politically expensive for them to engage in pork barreling.

As the result of the growing demand of rational policy making, the Korean government introduced a systematic infrastructure investment management system shown in figure 7. When an infrastructure investment project is proposed by local governments or other related agencies, line ministries such as Ministry of Land and Transportation (MOLT) internally review the feasibility of the projects and request a budget from the Ministry of Strategy and Finance (MOSF). MOSF reviews the proposed project by asking the government think tank, Korea Development Institute (KDI), to conduct a prefeasibility study (PSF). Around $40 \%$ of proposed projects by MOLT are rejected owing to the results of the PSF. Even if the PSF result supports a project, MOLT performs another round of the feasibility studies to develop a concrete plan. MOLT usually does not reject a project at the feasibility study stage, but it uses the feasibility study results to prioritize projects that passed the PSF. After the National Assembly reviews a project and budget approval has been granted, MOLT provides a schematic and detailed outline of the project.

The next stage is the selection of a construction company. The Public Procurement Service follows a standard procedure and selects the contractor. Although the total project costs are confirmed at the stage of the procurement, project costs can change due to a variety of reasons. When a contractor presents a claim indicating a change in the project cost, MOSF systematically reviews the request using a total cost management system. Using an electronic management system called D-brain to track changes in costs, MOSF can prevent arbitrary changes in project costs. Finally, after completion of the project, MOLT assesses whether the project achieved the intended goals using a 
postevaluation study.

Notably, this rational infrastructure management involves different ministries that share the responsibility for overseeing infrastructure investment. This allows the government to correct errors and address the unanticipated risks of investment decisions made in the previous stage. Another other important feature is the PSF carried out by MOST. As a gatekeeper of budgets, MOST cannot accept all projects proposals submitted by line ministries and should provide good reasons for rejecting a given project. MOST uses the PSF as a major tool in making budgetary decisions connected to infrastructure. In the following section, we discuss how the PSF works in Korea.

\section{The Prefeasibility Study}

In Korea, the feasibility study for infrastructure projects is mainly done by line ministries such as MOLT. Line ministries contract the government think tanks, university professors, and/or private companies to evaluate the economic, technical, and

Figure 5. PFS Structure

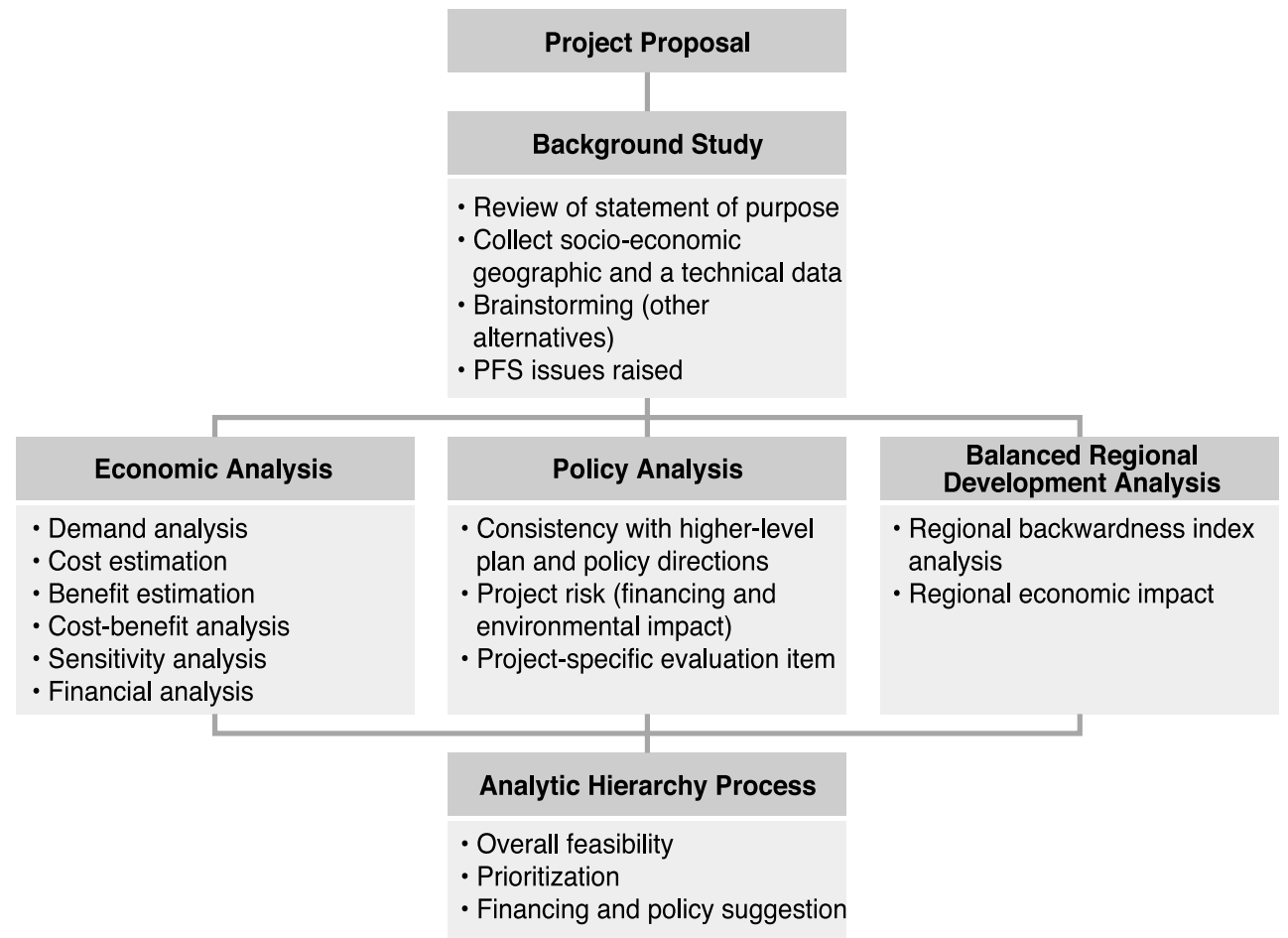

Source: Park, 2007 
policy feasibilities. The major drawback of the feasibility studies undertaken by line ministries is that the results are not necessarily objective, as line ministries frequently manage to influence the feasibility study team in such a way as to get it to produce favorable results for them. As William Niskanen postulates, line ministries enjoy more power by launching more projects with bigger budgets. Hence, the results of the feasibility studies led by line ministries tend to underestimate costs and overestimate benefits.

MOSF became concerned about the validity of the results of line ministries' feasibility studies. For instance, between 1994 and 1998, only 1 out of a total of 32 projects was disapproved by MOLT after feasibility studies were conducted. In response, in 1999 MOSF began independently performing its own PFSs. MOSF's PFSs cover most large-scale projects whose total costs are $\$ 50$ million USD or more. As figure 7 shows, economic feasibility is evaluated using cost-benefit analysis. Policy feasibility assesses environmental impact, effect on regional development, residents' support of the project, and other policy issues. As these economic and policy feasibility assessments are beyond the expertise of MOSF public officials, the ministry asks KDI to perform the PFSs.

Compared to line ministries' feasibility studies, MOSF's PFSs show a high level of transparency. The primary feature enhancing the transparency of MOSF's PFSs is the multidisciplinary PFS team (Park 2007, p. 129). When KDI reviews a project, three or more organizations are involved. A typical PFS team consists of KDI researchers, university professors, and private company experts. These various participants have their

Figure 6. Number of Newspaper Articles Referring to PFSs, 1999-2005

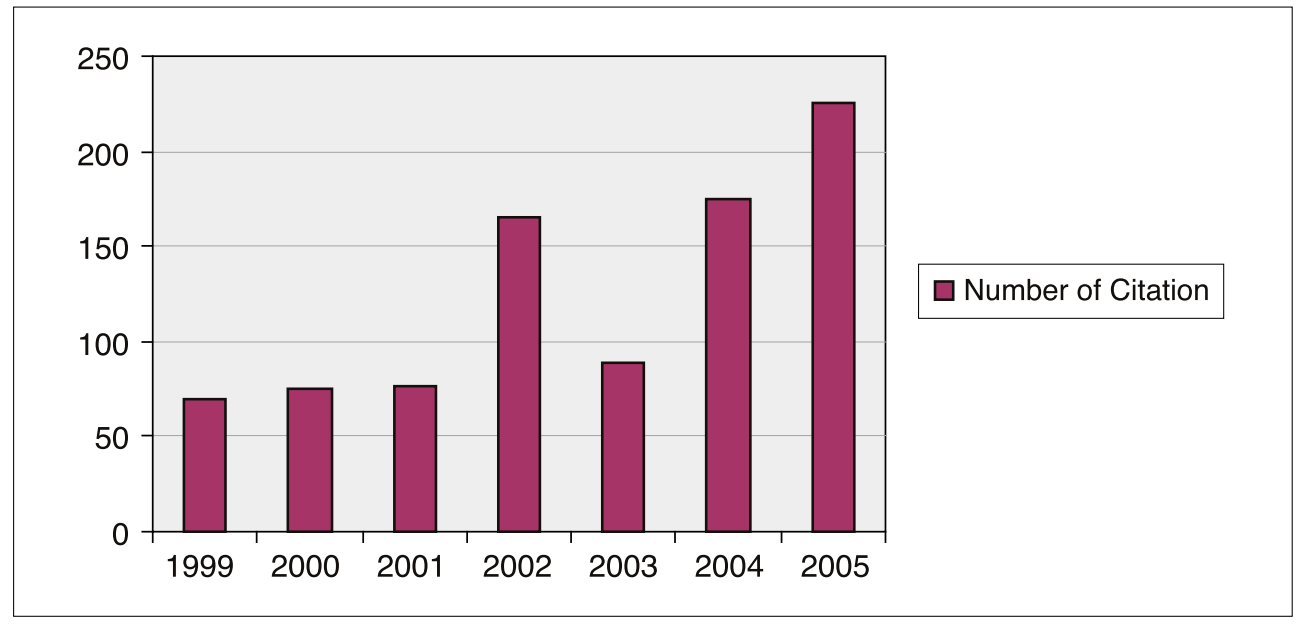

Source: Korea Transportation Database, www.ktdb.go.kr 
own expertise, and the PFSs reflect their different views. The other feature is the openness of MOSF's PFS process. KDI invites external experts to review midterm and final PFS reports. The reports are also reviewed by MOSF and line ministries, which provide their own comments to KDI. In addition, as shown in figure 8, the public and mass media have paid more attention to PFSs over the years. Once PFS results are publicized, politicians whose district's project is rejected cannot easily overturn the PFS result. The mass media and competing politicians are quick to draw attention to attempts on the part of politicians to allocate budgets despite unfavorable PFS results. Hence, PFSs significantly reduce pork barreling in infrastructure investment projects by securing a high level of transparency.

As PFSs increase the transparency of infrastructure investment, they have become standard procedure in infrastructure investment decision-making in Korea. As shown in table 5, as of 2010, more than 465 major infrastructure projects have received PFSs, and around $40 \%$ of them have been rejected. This rejection rate is very high, especially considering that most proposed projects evaluated through feasibility studies by the Ministry of Land and Transportation in the 1990s were approved.

The PFS, however, is not perfect. While KDI performs an intensive cost-benefit analysis, there is much room for improving the accuracy of the estimation of demands, benefits, and costs. The project costs estimated by the PFS are different from what the project ends up costing when it is actually implemented. Sometimes, there is a wide gap between expected demand and actual demand. These inaccuracies are not the result of bias but of limitations of available data and methodologies.

Acknowledging this limitation of policy analysis at the planning and decision stage, the Korean government has introduced a total project cost management system. If there is a large variation in project costs or demand, the Korean government reanalyzes the

Table 5. Number of Infrastructure Projects Receiving a PFS, 1999-2010

\begin{tabular}{l|r|r|r|r|r|r|r|r|r|r|r|r|r}
\hline & 1999 & 2000 & 2001 & 2002 & 2003 & 2004 & 2005 & 2006 & 2007 & 2008 & 2009 & 2010 & Total \\
\hline Road & 11 & 11 & 20 & 10 & 12 & 23 & 11 & 27 & 30 & 11 & 21 & 4 & 191 \\
\hline Railway & 2 & 7 & 14 & 7 & 6 & 12 & 6 & 11 & 5 & 2 & 5 & 6 & 83 \\
\hline Harbor & 1 & 5 & 1 & 1 & 3 & 2 & 1 & 3 & 1 & 4 & 2 & 2 & 26 \\
\hline Airport & 0 & 1 & 1 & 0 & 0 & 0 & 0 & 0 & 0 & 1 & 1 & 0 & 4 \\
\hline $\begin{array}{l}\text { Water } \\
\text { Resource }\end{array}$ & 1 & 1 & 0 & 5 & 3 & 0 & 0 & 1 & 1 & 2 & 12 & 6 & 32 \\
\hline Others & 4 & 5 & 5 & 7 & 9 & 18 & 11 & 10 & 8 & 17 & 20 & 14 & 128 \\
\hline Total & 19 & 30 & 41 & 30 & 33 & 55 & 29 & 52 & 45 & 37 & 61 & 32 & 464 \\
\hline
\end{tabular}


project feasibility. Also, the government puts the burden of proof on the construction companies if they request a larger budget than that of original plan. With the total cost management system, the government has been able to significantly reduce budget waste.

\section{Postevaluation Study}

In 2000, the Korean government introduced a law requiring postevaluation studies for infrastructure construction projects. According to the law, any construction projects that costs more than $\$ 50$ million USD should be evaluated within three years of completion. As of 2013, around 290 construction projects have received postevaluation studies. As shown in table 6, only 37 out of 267 transportation projects performed a cost-benefit analysis in the planning stages, which suggests that before MOSF began conducting its independent PSFs in 1999, most projects were not performing a cost-benefit analysis at their planning stage in the line ministries.

According to postevaluation results, around $91 \%$ of railway projects overestimated demand, as did $63 \%$ of highway projects. ${ }^{6}$ Such a systematic overestimation of demand goes along with the inflation of estimated net benefits of projects. While PFSs have significantly contributed to reducing the arbitrary manipulation of net benefits of infrastructure projects, inaccuracy in estimating and benefits and costs persists. Even though such inaccuracy stems in part from methodological limitations and lack of sufficient data used for estimation, we can still reasonably suspect that some infrastructure projects are being implemented in the absence of economic considerations.

Table 6. Number of Postevaluation Studies Performed since 2001

\begin{tabular}{c|c|c|c}
\hline & $\begin{array}{c}\text { Number of } \\
\text { Studies }\end{array}$ & $\begin{array}{c}\text { Number of Projects } \\
\text { That Used Cost-Benefit } \\
\text { Analysis }\end{array}$ & $\begin{array}{c}\text { Number of Projects } \\
\text { That Used Demand } \\
\text { Estimation }\end{array}$ \\
\hline Transportation Projects & 267 & 37 & 237 \\
\hline Other Projects & 23 & 11 & 19 \\
\hline Total & 290 & 48 & 256 \\
\hline
\end{tabular}

6. The analysis was done by National Assembly member Minseok Park with the support of National Assembly Budget Office. 


\section{DISCUSSION AND CONCLUSION}

This article reviews how infrastructure investment has evolved over the decades in Korea. Like other less developed countries, Korea has faced challenges in infrastructure provision such as a lack of usable investment funds, inexperience in planning and managing megaprojects, political pork barreling, and unpredictable economic and social conditions. Hence, neither the market nor government could solve these problems independently.

Korea has benefited from using a systematic administrative process that rationalizes rather than politicizes infrastructure investment decision. Less developed countries usually face political instability, and so their infrastructure investment and other economic development plans tend not to be well coordinated because of the weak institutionalization of the policy-making process. The Korean government has minimized such political and administrative risks with two approaches: utilization of a strong planning agency and performance monitoring. In 1961, the Korean government empowered the Economic Planning Board (EPB) to design five-year economic plans, which were politically supported as well, although there were conflicts between the Ministry of Construction and Transportation and the EPB over budgets and prioritization of projects that the five-year plans did not completely resolve. Mediation in these conflicts was provided by successive presidential administrations, which closely monitored the outcomes of investment decision in the 1970s. Such performance monitoring forced bureaucrats to commit to assiduous policy making and made clear who was responsible for investment decisions. These planning and performance monitoring practices, in turn, increased the managerial capacity of public organizations in infrastructure management.

One might claim that the political leadership is critical for successful infrastructure investment in developing countries. Admittedly, infrastructure investment is not be feasible without strong political support as it requires a considerable amount of national resources. However, as the Gyeongbu expressway and the four-rivers project suggest, political leadership without the relevant analytical information can lead to unsatisfactory results. Moreover, political leadership is not a well-defined concept, and it will mean different things in different countries depending on the level of democratization and economic development. While there are a few exceptions, as the economy grows and democracy further develops in Korea, most infrastructure decisions are being made via rational policy-making processes such as the coordination of national and local government development plans, the adoption of PFSs, total project cost management, and postevaluation studies. This suggests that administrative capacity building for making better infrastructure decisions is critical for the expansion of the infrastructure of developing countries. 
The other important lesson to be drawn from the Korean government's approach to infrastructure investment is the wisdom of establishing stable funds to support it. In 1994, the Korean government established a special fund for transportation infrastructure investment. The fund enabled the government to more accurately predict how much money was available for infrastructure and helped it form long-term investment plans. In addition, special funds can help the government facing the pressure of budget deficits to avoid relying too much on private or foreign funds to supply infrastructure. In fact, the government of developing countries tend to spend budgets on programs whose benefits are immediately apparent to the public rather than on infrastructure, whose benefits accrue over the long term. Therefore, if governments fail to create stable funds earmarked for infrastructure investment, they will end up having to borrow money at a higher cost from private and/or foreign investors.

Like other countries, Korea currently faces budget constraints, which makes it difficult to finance many projects. As a partial solution to the problem of budget constraints, the government has begun relying on private funds. Recent instances of heightened public-private partnership, however, suggest that there is no guarantee that the private sector will provide a low-cost, high quality infrastructure, as it has its own interests, not those of the public, at heart. In particular, because the government faces information asymmetry when it makes a contract with private firms, it unduly undertakes financial risks by guaranteeing a minimum revenue to private investors. At the same time, the government has to pay managerial costs that arise from the privateinterest maximization behaviors of private companies.

How to manage the public-private partnership is also a challenge for many developing countries that rely on FDI for the supply of infrastructure. To alleviate the information asymmetry between the private and public sectors, governments need to engage in rational policy analysis to assess economic and policy feasibility. While rational policy analysis is not perfect, as the Korean experience suggests, its institutionalization can help governments improve their administrative capacity. At the same time, it forces the private sector to reveal its concealed information, which mitigates the information asymmetry. Therefore, better planning and analysis is the right way for developing countries to improve infrastructure investment.

\section{REFERENCES}

Amsden, A. H. 1989. Asia's next giant: South Korea and late industrialization. New York: Oxford University Press.

Flyvbjerg, B., N. Bruzelius, \& W. Rothengatter. 2003. Megaprojects and risk: An 
anatomy of ambition. Cambridge: Cambridge University Press.

Hirschman, A. 1958. The strategy of economic development. New Haven, CT: Yale University Press.

Korean Ministry of Construction and Transportation [MOCT]. 1999. Prescriptions for efficient public investment projects.

Korean Transport Institute [KOTI]. 2012. A study on 2030 transportation policy reform.

Lucas, R. E. 1993. Making a miracle. Econometrica, 61(2): 251-272.

Park, H. 2007. Preliminary feasibility study: Performance and challenges In K.-S. Kim (ed.), Improving public investment management for large-scale government projects, focusing on feasibility studies (pp. 125-137). Seoul: KDI Press.

Ramamurti, R., \& J. P. Doh. 2004. Rethinking foreign infrastructure investment in developing countries. Journal of World Business, 39(2): 151-167. doi: http://dx. doi.org/10.1016/j.jwb.2003.08.010.

Stiglitz, J. E. 2000. Economics of the public sector (3rd ed.). New York: Norton.

Todaro, M. P., \& S. C. Smith. 2003. Economic development. Addison-Wesley Higher Education.

Weimer, D. L., \& A. R. Vining. 2005. Policy analysis: Concepts and practice (4th ed.). Upper Saddle River, NJ: Prentice Hall.

Wilson, James Q. 1989. Bureaucracy: What government agencies do and why they do it. New York: Basic Books. 